\title{
The lost scholarship of changing curricula
}

\section{BOOK TITLE:}

Africanising the curriculum: Indigenous perspectives and theories

\section{BOOK COVER:}

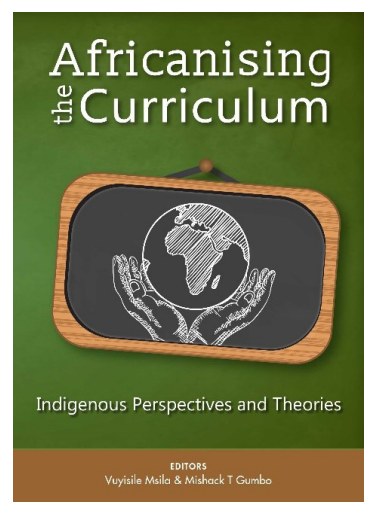

\section{EDITORS:}

Vuyisile Msila and Mischack T. Gumbo

ISBN:

9780992236076 (softcover)

\section{PUBLISHER:}

AFRICAN SUN MeDIA,

Stellenbosch; ZAR325

\section{PUBLISHED:}

2016

\section{REVIEWER:}

Jonathan Jansen

\section{AFFILIATION:}

Centre for Advanced Study in the Behavioral Sciences, Stanford University, Stanford, California, USA

EMAIL: jdjansen007@gmail.com

\section{HOW TO CITE:}

Jansen J. The lost scholarship of changing curricula. S Afr J Sci. 2017;113(5/6), Art. \#a0209, 2 pages. http://dx.doi. org/10.17159/sajs.2017/a0209

\footnotetext{
(c) 2017. The Author(s). Published under a Creative Commons Attribution Licence.
}

We know from curriculum history that in times of social crises, there emerges calls for changes to the content of what is taught and learnt in schools and universities. In the days leading up to and following the installation of post-colonial government, that call for curriculum change was heard across continents where Europeans had taken whole countries as possessions. So too in the expectant period that followed Nelson Mandela's release from prison (1990) and the first years of post-apartheid democracy (1994). There are always two principal driving forces behind such calls for curriculum change: the one is symbolic (to signal change intentions - political, in other words) and the other is practical (to change what happens in classrooms - pedagogical, in other words).

The call for 'Africanisation' of curricula is at least as old as the Republic of Ghana, the first African country to gain independence - in 1961. That call could be summarised as follows. The colonial curriculum is Eurocentric and perpetuates Western bias. Students are more likely to learn European history, geography, literature and politics, than anything about those subjects in Africa. In the process, the great social, scientific and literary achievements of Africa in the pre-colonial period are ignored and undermined. When Africa is taught it is through the racist lens of inferior, incompetent, incapable states and individuals who required the colonial power to give the natives civilization through education, religion, governance and infrastructure - like parliament and piped water. Without the 'benevolence' of colonial rule, it follows, Africa would remain backward and barbaric. What is now required, in response, is a recovery of African knowledge and achievements from a distant past and which should be represented at the heart of the curriculum.

The South African university student uprising of 2015-2016 represented one such social crisis, by which I mean a massive disruption in South African society. Unsurprisingly, peaceful protests saw calls for the transformation of the university curriculum followed by more violent protests demanding the decolonisation of the curriculum. In record time, books appeared on these student protests giving academic veneer to the calls for changing the curriculum, both in its symbolic forms (sculptures, paintings, building names) and its practical expression in teaching and learning.

The collection of essays assembled by Vuyisile Msila and Mischack Gumbo comes in the wake of the recent South African student uprising and is therefore a timely collection of writings that speak to the curriculum angst in the student body and, more broadly, among university leaders. This co-edited book of 13 chapters and 10 authors (the editors each wrote four and an additional co-authored chapter) has topics ranging from the African Renaissance and African leadership to indigenous knowledge and the 'revival of the university'. Specific subjects include science education, teacher education and the decolonisation of curricula. In other words, a veritable mixed bag of topics from rather mainstream concerns such as 'mixed methods research' to the ambitious promise of 'a cultural revolution'.

The editors frame their contribution to the curriculum debates as 'Africanisation' rather than 'decolonisation' despite a nominal reference to the latter in an opening chapter - which raises questions about meaning. Are these the same or similar constructs? Or does one construct subsume the other? We should begin this book review at this point.

In the social sciences, how you answer important curriculum questions depends on whom you ask, where and when. In its earliest forms following European rule, the Africanisation of the curriculum was meant simply as something opposite to, and in contrast with, the Europeanisation of the curriculum, so to speak. Where Europe was at the centre of colonial education in schools and universities, Africa should now occupy the centre as the organising principle around which knowledge, values and skills should be delivered for purposes of teaching and learning: a simple curriculum exchange.

A weaker version of Africanisation called for an additive model rather than a re-centred one. Here African knowledge should simply be added onto what already exists. The curriculum call, in this instance, was for inclusion and extension of African knowledge. Some would call this less radical version a contributionist (or 'us-also') approach to curriculum. And then there was a more radical call for curriculum change after colonial rule which demanded neither re-centring or contributory approaches but replacement - in other words, replace colonial knowledge with African knowledge: us without them. This more radical approach resonates with the more strident calls among students for the decolonisation of the curriculum.

The broad approach, at least from the perspective of the editors of Africanising the Curriculum, is one of re-centring - meaning the placement of Africa at the centre of the curriculum enterprise because 'Africans cannot ignore the Western belief systems' ( $p$. iii) for 'humanity shares some knowledge forms and perspectives' (p. iii). While the curriculum position is accommodationist, the plea throughout the book is for an assertive African knowledge and identity at the heart of curriculum theory and practice.

Unfortunately for this book, its moderate Africanist appeal has been overtaken by a much more militant approach to the institutional curriculum to which several of the former white universities have already responded with the inevitable establishment of 'committees' to contain student demands. Not that the core theses of the student activists are irrelevant. It is still true that African thought and ideas are unevenly spread across university disciplines in public universities.

But curriculum transformation did not stand still at South African universities before or since 1994. At the English universities - despite the exaggerated claims of some activists - there has been significant progress in transforming institutional curricula from the impressive African archaeological discoveries at Wits University to the knowledge 
recovery project of the University of Cape Town centred on Timbuktu in Mali. At the Afrikaans universities, curriculum transformation informed by Africanisation has been less visible but there are important niche areas such as the influential African Law programme at the University of Pretoria or the powerful research programme in Southern African history at the University of the Free State.

Even so, more could be done to bring a broader Pan-African influence across the university curriculum. In education, for example, some English universities still hold on to a curriculum heavily centred on European theorists like Bernstein and Bourdieu, while teacher preparation in some Afrikaans universities continues to be influenced by fundamental pedagogical thought from the apartheid era. The calls for curriculum transformation, whether in the traditional form of Africanisation or its more radical expression as decolonisation, are not without epistemological and political merit.

But the call for Africanisation (and decolonisation) is not without serious problems. It is hard not to conclude from the chapters in this edited book that Africanisation means black African. There is a racial and ethnic chauvinism at play, which is betrayed through both the limited range of authorship and the deployment of key words like 'pure' forms of the African curriculum. Where is the focus on complex Khoisan histories as in the research of Michael Besten? Or South African Indian symbolic knowledges presented in the writings of Devarakshanam (Betty) Govinden or radical Afrikaans literary explorations in works from Andre Brink to Hein Willemse - and new breakthroughs in creative fiction and poetry of Shirmoney Rhode and Ronelda Kamfer? It is difficult not to conclude that what is being proffered is often an essentialist black African version of Afrikaner nationalist thought.

Which of course raises a critical issue about knowledge, curriculum and identity in the 21 st century. To insist on an African versus European curriculum in the age of globalisation is naïve. Our knowledges are integrated both at the level of knowledge as well as in the hands of knowledge workers. Our leading intellectuals stand with their feet in many worlds, travelling across borders and collaborating with their colleagues in Asia, Latin America and the large, very diverse 'West'. The insistence on a 'them vs us' dichotomy this side of colonial rule is anachronistic and unhelpful for those who actually do research and writing across the world; examples of such powerful North-South collaboration (led, incidentally, by black scientists from South Africa) are in the field of health sciences at the University of KwaZulu-Natal (in the area of HIV/AIDS research) and in cardiovascular research at the University of Cape Town. Not only is world knowledge entangled with theory from elsewhere - Southern Theory, for example - but new discoveries are being made in the social and natural sciences through transborder partnerships. Remaining trapped in a discourse of 'the West vs the rest of us' is to ignore changes in knowledge work over the past three decades since dependency theory held us captive. It is also to ignore the changing authority of African scholars and scholarship.

The continued grievance of a hapless African scholarship being dominated by Western 'knowledge and power' betrays an inferiority complex, on the one hand, and a lack of intellectual activism on the other hand. Those who complain loudest about a colonised curriculum often do the least to lead major research projects, produce the influential research books, edit influential African journals and speak truth to global power. The curriculum does not change itself. It changes in collaboration as well as competition with scholars around the world. It requires new bodies of research generated by and with African scholars across the disciplines. It also demands new authorities - new PhD graduates who are research ambitious and can generate theory and research which break new ground from field work on African research questions. Where is this scholarship?

Neither an Africanised curriculum nor a decolonised curriculum adequately come to terms with the reality of entangled knowledges represented in the realities of a 21st-century academy in which the lines are increasingly blurred between the identity, ownership and authority of scholarly transactions. It is time for curriculum theory and practice to move on from becoming stagnant and entrapped in a purist language of another era. 